\title{
Assessment Of Heavy Metal Pollution Of Waste Dump Sites In Kwara State Using Carica Papaya, Musa Spp And Cocorhrous Olitorous As Indicators
}

\author{
Ogundele, D. $\mathrm{T}^{1}$, Bodunde, V. T ${ }^{2}$, Bale, A. $\mathrm{T}^{3}$ \\ ${ }^{1}$ Department of chemical, geological and physical Sciences, chemistry program Kwara State University, \\ Malete, Nigeria \\ 2 Department of chemical, geological and physical Sciences, chemistry program Kwara State University, \\ Malete, Nigeria \\ 3 Department of chemical, geological and physical Sciences, chemistry program Kwara State University, \\ Malete, Nigeria
}

\begin{abstract}
Plant fruits and vegetables grown on mixed waste dumpsites were used as bio indicators of heavy metal pollution of three waste dumpsites in Ilorin Kwara State Nigeria.

The samples were digested using Wet-oxidation method and heavy metals in the digest were analyzed by Atomic Absorption Spectrophotometer Technique. Carica Papaya, Musa Spp and Cocorhrous Olitorous samples were collected from contaminated and uncontaminated sites.

Copper concentrations of carica- papaya, Musa spp, and cocorhrous olitorous from the contaminated sites were found between 0.15-0.23 mg/kg in Abayawo, $0.13 \mathrm{mg} / \mathrm{kg}$ in Okolowo, and $0.10 \mathrm{mg} / \mathrm{kg}$ in Itanmo. Zinc was found between 21.25-42.75 mg/kg in Abayawo, $20.00 \mathrm{mg} / \mathrm{kg}$ in Okolowo, and $11.00 \mathrm{mg} / \mathrm{kg}$ in Itanmo. Pb and Cd were found below the detection limit of the instrument.

Heavy metals in the uncontaminated site samples were found between 0.10-0.23 mg/kg Copper, 0.75-31.75 $\mathrm{mg} / \mathrm{kg}$ Zinc. Cadmium and lead were found comparatively below detention limits in all the samples.

Mean concentrations of metals were higher in Abayawo dumpsite than other dumpsites. The mean concentration of $\mathrm{Cu} 0.56 \mathrm{mg} / \mathrm{kg}$ and $\mathrm{Zn} 30.75 \mathrm{mg} / \mathrm{kg}$ are well above the mean concentration of metals from the control site (Oloje) $0.15 \mathrm{mg} / \mathrm{kg}$ and $24.58 \mathrm{mg} / \mathrm{kg}$ Copper and Zinc respectively.

Base on this study, the three waste dumpsites are polluted with heavy metals (Copper, Zinc), which can pose great health risk and hazards on food chain.
\end{abstract}

Keywords- Heavy metals, dumpsites, Carica papaya, musa spp, Cocorhrous Olitorous

\section{INTRODUCTION}

The continuing increase in population and the rapid increase of industrial processes particularly in major cities have led to the emergence of development that have greater impact on human and the environment. The industrial insurgency gave birth to environmental pollution and the greater volume of industrial chemical discharges has added to the growing pack of untreated domestic waste which contains heavy metals. The discarding of domestic, commercial and industrial garbage which may contain toxic materials such as $\mathrm{Pb}, \mathrm{Cu}$, $\mathrm{Cd}, \mathrm{Hg}, \mathrm{Mn}, \mathrm{Zn}$ from batteries, insecticides, nail polish cleaners, polyvinyl chloride made containers, pesticides and other various products in the world is a predicament that continues to grow with human development. Research has shown that most forms of waste disposal have side effect on the environment, public health, and local economies [1]. Several heavy metals have been known to be toxic to man for centuries. Numerous hazardous heavy metals are inhaled by humans and animals almost every day. The major concern with heavy metals is their ability to accumulate in the environment and thereby passing up the food chain.

Heavy metals are very harmful because of their non-biodegradable nature, long biological half-lives and their potential to accumulate in different body parts. Most of the heavy metals are extremely toxic because of their solubility in water. Even low concentrations of heavy metals have damaging effects to man and animals because there is no good mechanism for their elimination from the body.

Nowadays heavy metals are ubiquitous because of their excessive use in industrial applications. Wastewater contains substantial amounts of toxic heavy metals, which create problems [2]. Excessive accumulation of heavy metals in agricultural soils through wastewater irrigation may not only result in soil contamination, but also affect food quality and safety [3].

Food and water are the main sources of our essential metals; these are also the media through which we are exposed to various toxic metals. Heavy metals are easily accumulated in the edible parts of leafy vegetables, as compared to grain or fruit crops [4]. Vegetables take up heavy metals and accumulate them in their edible and inedible parts in quantities high enough to cause clinical problems both to animals and human beings consuming 
these metal-rich plants. This study thus aimed at assessing the intake of trace metals by plants and vegetables grown on the waste dumpsites as indication of heavy metals contamination and the probable routes of exposure

\section{Materials And Methods}

The study sites are the major waste dumpsites located in Ilorin, Kwara State metropolis. They are Abayawo waste dumpsite, Itanmo waste dumpsite, and Okolowo waste dumpsite. The control samples were collected from Oloje estate. Abayawo waste dumpsite lies between latitude $08^{\circ} 30^{\prime} 25.2^{\prime \prime} \mathrm{N}$ and longitude $04^{\circ}$ $30^{\prime} 33.2^{\prime \prime}$ E. It is a residential area with over 2000 people. It is an abandoned dumpsite turned to a farmland. It comprises heterogeneous wastes such as paper, plastics, and leathers, wood, sewage sludge, leachates, spent batteries e.t.c. The dumpsite is characterized by plants averagely growing on it. The activities going on around the site include farming, poultry, school, residency, and clinic. Itanmo waste dumpsite was a government approved site for citizens to dump their waste. The dumpsite lies between latitude $08^{\circ} 29^{\prime} 35.8^{\prime \prime} \mathrm{N}$ and longitude $04^{\circ} 28^{\prime} 56.4^{\prime \prime}$ E. It is a mixed site, the site consist of heterogeneous municipal wastes such as plastics, leather, papers, textiles, rubber, broken glasses, industrial waste, tyres, wood, saw dust, $\mathrm{Pb}$ batteries. Okolowo dumpsite is an abandoned waste dumpsite. The dumpsite lies between latitude $08^{\circ} 32^{\prime} 26.2^{\prime \prime} \mathrm{N}$ and longitude $04^{\circ} 28^{\prime} 56.4^{\prime \prime}$ E. ; it is constituted by heterogeneous municipal wastes such as papers, tyres, textiles, cathode ray tubes, plastics, rubber, wood, $\mathrm{Pb}$ batteries etc. Oloje estate is a residential area with over 3000 people. The estate is located between latitude $08^{\circ} 30^{\prime} 09.2^{\prime \prime} \mathrm{N}$ and longitude $04^{\circ} 30^{\prime} 37.8^{\prime \prime} \mathrm{E}$. Plants are usually grown within the estate for consumption purpose. Plant samples from this site were used as control samples.

Four pooled samples of different species of carica papaya, musa spp, cocorhrous olitorous were collected from the contaminated sites into polyethylene bags. The fruits and vegetable eaten by human and animals were selected based on their availability on the contaminated sites. They were identified at Plant and Environmental Biology Department Herbarium Unit Kwara State University Malete, Nigeria, thereafter; the samples were washed under running tap to remove adhered soils. Plant samples were sun dried and oven dried for 48 hours at $80^{\circ} \mathrm{C}$ and milled to $<2 \mathrm{~mm}$.

\section{Geographical coordinates of sampling points}

Study Location Latitude Longitude

Abayawo Fruits \&

vegetable Sample $\quad 08^{\circ} 30^{\prime} 25.2^{\prime \prime} \quad 4^{\circ} 30^{\prime} 33.2^{\prime \prime}$

Itanmo Fruits Sample $08^{\circ} 29^{\prime} 35.8^{\prime \prime} \quad 04^{\circ} 28^{\prime} 56.4^{\prime \prime}$

Okolowo Fruits Sample 08 $32^{\prime} 26.2^{\prime \prime} \quad 04^{\circ} 28^{\prime} 56.4^{\prime \prime}$

Oloje Fruits \&

Vegetable Sample $\quad 08^{\circ} 30^{\prime} 09.2^{\prime \prime} \quad 04^{\circ} 30^{\prime} 37.8^{\prime \prime}$

All glass and plastic wares used were soaked in detergent solution overnight, thoroughly rinsed under running tap, soaked in dilute nitric acid for $24 \mathrm{hrs}$ and washed thoroughly with de-ionized water. $10 \%$ duplicate analysis was carried out along with the digestion process as the quality control. Wet ashing/digestion procedure was chosen for the oxidation of fruits and vegetable samples as adapted from . [6]

$1 \mathrm{~g}$ each of thawed and homogenized whole fruit and vegetable samples were digested using $10 \mathrm{~mL}$ concentrated $\mathrm{HNO}_{3}$ at $150^{\circ} \mathrm{C}$ for 30 minutes on a tectator (digestion Apparatus), until clear solution was obtained indicating the end of digestion. The digests were allowed to cool, filtered and then diluted to $25 \mathrm{~mL}$ in a standard flask. $\mathrm{Pb}, \mathrm{Cd}, \mathrm{Cu}$ and $\mathrm{Zn}$ concentrations in fruits and vegetables were quantified by flame atomic absorption spectrophotometry (AAS) using a Buck scientific Atomic Absorption machine model 210 VAP instrument with an air-acetylene flame. The wavelength of $\mathrm{Cd}, \mathrm{Pb}, \mathrm{Cu}$ and $\mathrm{Zn}$ were 228.9, 283.2, 324.7, $213.9 \mathrm{~nm}$ respectively. The values were expressed in $\mathrm{mg} / \mathrm{kg}$ plants. $10 \%$ duplicate analyses were carried out along with the digestion process to control the accuracy of the methods of analysis. Blind samples which are solutions of pure analyte with known concentrations were inserted into the sample digests to assess the performance of the instrumental analysis. Instrumental and procedural blanks were also added to indicate contamination. Accuracy and precision of the analysis were good in all cases, confirming the validity of the method used. All the statistical analysis and calculations were done using Microsoft excel 2007. Range, arithmetic mean, standard deviation were calculated. For statistical analysis of non-detectable concentrations, the value of the detection limit was assigned. The data was analyzed using Paired sample T- test to find out the statistical difference between the mean values of heavy metal concentrations in the contaminated and the control plants.

\section{Results \& Discussion}

The concentration of heavy metals presents in the fruits and vegetable samples from the three studied sites and from the control area are shown in Tables 1, 2, and 3 respectively. Range and mean levels of $\mathrm{Pb}, \mathrm{Cd}$, $\mathrm{Cu}$ and $\mathrm{Zn}$ in the fruits and vegetables are: $<\mathrm{ND},<\mathrm{ND}, 0.10-0.56(0.26 \pm 0.14)$ and 11.00-30.75 (20.58 \pm 3.65$)$ 
$\mathrm{mg} / \mathrm{kg}$ respectively. In the sample from the control site, the concentrations of $\mathrm{Pb}, \mathrm{Cd}, \mathrm{Cu}$ and $\mathrm{Zn}$ are $<\mathrm{ND},<\mathrm{ND}$, $0.10-0.23$ and $0.75-31.75 \mathrm{mg} / \mathrm{kg}$ respectively.

Table 1. Mean Concentration of the heavy metal in Abayawo Dumpsite

\begin{tabular}{|c|c|c|c|}
\hline \multicolumn{4}{|c|}{$\begin{array}{lll}\text { Sample } & \text { Carica papaya musa spp Cocorhrous olito. }\end{array}$} \\
\hline $\mathrm{Cu}(\mathrm{mg} / \mathrm{kg})$ & 0.18 & 0.15 & 0.23 \\
\hline $\mathrm{Zn}(\mathrm{mg} / \mathrm{kg})$ & 42.75 & 21.25 & 28.25 \\
\hline $\mathrm{Pb}(\mathrm{mg} / \mathrm{kg})$ & ND & ND & ND \\
\hline $\mathrm{Cd}(\mathrm{mg} / \mathrm{kg})$ & ND & ND & ND \\
\hline \multicolumn{4}{|c|}{$\begin{array}{l}\mathrm{ND}=\text { Not Detected } \\
\text { Table 2. Mean Concentration of the heavy metal in Okolowo and } \\
\text { Itanmo Dumpsites }\end{array}$} \\
\hline Sample & \multicolumn{2}{|c|}{ Carica papaya.(OK), } & carica papaya(IT) \\
\hline $\mathrm{Cu}(\mathrm{mg} / \mathrm{kg}$ & 0.13 & & 0.10 \\
\hline $\mathrm{Zn}(\mathrm{mg} / \mathrm{kg})$ & 20.00 & & 11.00 \\
\hline $\mathrm{Pb}(\mathrm{mg} / \mathrm{kg})$ & ND & & ND \\
\hline $\mathrm{Cd}(\mathrm{mg} / \mathrm{kg})$ & ND & & ND \\
\hline
\end{tabular}

Table 3. Mean Concentration of the Heavy metal in Oloje site (Control)

\begin{tabular}{lllc}
\hline Sample & Carica papaya & musa spp & Cocorhrous olito. \\
& \multicolumn{3}{c}{} \\
\hline $\mathrm{Cu}(\mathrm{mg} / \mathrm{kg})$ & 0.13 & 0.10 & 0.23 \\
$\mathrm{Zn}(\mathrm{mg} / \mathrm{kg})$ & 11.25 & 0.75 & 31.75 \\
$\mathrm{~Pb}(\mathrm{~m} / \mathrm{kg})$ & $\mathrm{ND}$ & $\mathrm{ND}$ & $\mathrm{ND}$ \\
$\mathrm{Cd}(\mathrm{mg} / \mathrm{kg})$ & $\mathrm{ND}$ & $\mathrm{ND}$ & $\mathrm{ND}$ \\
\hline
\end{tabular}

\section{$\mathrm{ND}=$ Not Detected}

The concentrations of $\mathrm{Zn}$ were several folds higher in the plants from the contaminated sites than in the control site. Although, the $\mathrm{Zn}$ levels in the plants were lower than the recommended limits of $60.0 \mathrm{mg} / \mathrm{kg}$ in normal plant by [6]. Lead levels which range from $30-300 \mathrm{mg} / \mathrm{kg}$ have been considered phytotoxic to plants. Concentrations of $\mathrm{Cd}, \mathrm{Cu}$ and $\mathrm{Zn}$ are within the recommended limits of 0.05-2.0, 5.0-20.0 and 10-150 mg/kg respectively [7].There is a few studies which also demonstrated contamination of forage plants by metallurgical activities. [8] reported lead concentration in fodder collected from around $\mathrm{Pb} / \mathrm{Zn}$ smelter and from nonindustrialized area as $29.06 \pm 11.32 \mu \mathrm{g} / \mathrm{g}$ and $2.08 \pm 0.22 \mu \mathrm{g} / \mathrm{g}$, respectively. Also reported that the pasture near smelter unit contained $325 \mu \mathrm{g} / \mathrm{g}$ of $\mathrm{Pb}$. Human and animals get exposed to non permissible levels of heavy metals mainly through ingestion of contaminated food and water.

It is important to note from the results of this work that improper disposal of domestic and industrial wastes could lead to contamination of plants and water with consequent transfer to human. Biological samples such as blood, milk, air and fingernails have been used as indicator of heavy metal contamination [10]. Presented in Table 4 are the mean ( \pm SD) carica papaya, musa spp, corchrous olitorous $\mathrm{Pb}, \mathrm{Cd}, \mathrm{Cu}$ and $\mathrm{Zn}$ levels measured in both the contaminated and reference samples.

\begin{tabular}{|c|c|c|c|c|}
\hline Sites & $\mathrm{Cu}(\mathrm{mg} / \mathrm{kg})$ & \multicolumn{3}{|c|}{$\mathrm{Zn}(m g / \mathrm{kg}) \mathrm{Pb}(m g / \mathrm{kg}) \mathrm{Cd}(m g / \mathrm{kg})$} \\
\hline Abayawo & $0.56 \pm 0.388$ & $30.75 \pm 8.95$ & ND & ND \\
\hline Okolowo & $0.13 \pm 0.03$ & $20.00 \pm 2.00$ & ND & ND \\
\hline Itanmo & $0.10 \pm 0.00$ & $11.00 \pm 0.00$ & ND & ND \\
\hline Oloje & $0.15 \pm 0.06$ & $24.58 \pm 9.44$ & ND & ND \\
\hline Min. & $0.1 \pm 0.02$ & $11.00 \pm 0.01$ & ND & ND \\
\hline Max. & $0.56 \pm 0.38$ & $30.75 \pm 8.95$ & ND & ND \\
\hline
\end{tabular}

\section{$\mathrm{ND}=$ Not Detected}

Udosen and Amusan reported higher metal concentration in plants grown on dumpsites. This could be as a result of higher metals in the soil at the dumpsites which are subsequently accumulated by the plant grown on the dumpsites. It is also an indication that the concentration of metals in plant is dependent upon their concentration in the habitual soil environment [12]. Carica papaya shows the highest concentration of $\mathrm{Zn}$ and $\mathrm{Cu}$ in most of the sites than the level in the corresponding musa spp and corchorus olitorous. This is in line with the report of Justa and mench, micieta and murin. This could be due to low levels of $\mathrm{Pb}$ and $\mathrm{Cd}$ which interfered with normal $\mathrm{Cu}$ and $\mathrm{Zn}$ absorption system [14]. $\mathrm{Cu}$ retained in the fruits and vegetable on which human and animal feed on can be deposited in the organs such as liver and kidney leading to all sorts of chronic copper poisoning [15]. The results obtained also propose that absorption of trace essential metals in fruit and vegetable 
may not only depend on the total amount in plant, but also on the levels of toxic metals that are co-present in the dumpsites. Levels of $\mathrm{Cu}$ and $\mathrm{Zn}$ observed in the control plant samples were lower than those of the sampled plants. Although the reasons for this sharp difference in concentrations observed cannot be clarified with certainty. There are two possibilities. The elevated levels may be due to the nature of wastes deposited at the sites, Secondly; the environment around the control plants might be low in $\mathrm{Cu}$ and $\mathrm{Zn}$ concentration. In Nigeria, used rubber tires are usually burnt indiscriminately. The residues from the burnt tires which are known to contain high levels of $\mathrm{Cu}$ and $\mathrm{Zn}$ are disposed off in an illegal dumpsite in the vicinity where the plants are grown. This demonstrates that particular attention has to be paid to the trace $\mathrm{Cu}$ and $\mathrm{Zn}$ levels in Nigerian fruits and vegetables. There is scantiness of data on toxic and trace metal concentrations in fruits and vegetables in Nigeria. Hence, there are no reports in Nigeria to compare the results of the heavy metals concentrations in the control plants with. In future studies, fruits and vegetables sold in Nigeria markets should be often analysed to ascertain the trace metals, especially $\mathrm{Cu}$ and $\mathrm{Zn}$ levels.

\section{Conclusion}

The study showed less outrageous concentrations of $\mathrm{Pb}, \mathrm{Cd}, \mathrm{Cu}$ and $\mathrm{Zn}$ dumpsites, which does not suggest that the dumpsites are free of heavy metals which could have definite adverse impact on the environment but over a long period of time could start showing up. There is the need to control open dumping of hazardous waste on land. In addition, it is important to note from the results of this work that improper disposal of domestic and metallurgical wastes could lead to contamination of forage plants with consequent transfer to ruminants. Analysis of fruits and vegetables indicated that $\mathrm{Zn}$ concentrations can be abnormally raised for animals and man that continuously graze on contaminated dumpsites. High levels of $\mathrm{Zn}$ in fruits and vegetables can be potential threat to the animals' health and source of transfer to human. There is the need for proper management of domestic and metallurgical wastes in order to safeguard the environment and preserve human health.

\section{REFERENCES}

[1] Pacyna J. M and E. G. Pacyna, 2002. An assessment of global and regional emissions of trace metals to the atmosphere from anthropogenic sources worldwide Norwegian Institute for Air Research (NILU), Kjeller, Norway

[2] Chen, Y., Wang, C., \& Wang, Z (2005). Residues and source identification of persistent organic pollutants in farmland soils irrigated by effluents from biological treatment plants. Environment International. volume 31: pages 778-783.

[3] Muchuweti, M., Birkett, J. W., Chinyanga, E., Zvauya, R., Scrimshaw, M. D., \& Lester, J.N. (2006). Heavy metal content of vegetables irrigated with mixture of wastewater and sewage sludge in Zimbabwe: implications for human health. : pages 312-322.

[4] Mapanda F, Mangwayana E.N, Nyamangara J, Giller K.E (2005)."The effect of long term irrigation using wastewater on heavy metal contents of soils under vegetables in Harare Zimbabwe". Agric. Ecosystem. Environ. Volume 107: pages 151 - 165.

[5] Mapanda, F., Mangwayana. E. N., Nyamangara, J., \& Giller, K. E. (2005). The effects of long-term irrigation using water on heavy metal contents of soils under vegetables. Agriculture, Ecosystem and Environment. Volume 107: pages 151-156

[6] Doherty V.F, Sogbanmu T.O, Kanife U.C, Wright O (2012). "Heavy metals in vegetables collected from selected farm and market in Lagos, Nigeria". Journal of environmental science and toxicology. $6^{\text {th }}$ edition volume 1: pages $137-142$.

[7] Boularbah, A., Schwartz, C., Bitton, G., Aboudrar, W., Ouhammou, A. and Morel, J. L. (2006). Heavy metal contamination from mining sites in South Morocco: 2. Assessment of metal accumulation and toxicity in plants. Chemosphere, 63, 811-817

[8] Swarup, D., Patra, R. C., Naresh R., Kumar P. and Shekhar P. (2005). Blood lead levels in lactating cows reared around polluted localities: transfer of lead into milk. Sci Tot. Environ., 349, 67- 71.

[9] Swarup, D., Patra, T. R. C., Naresh, R., Kumar, P., Shekhar P. and Balagangatharathilagar, M. (2006). Lowered blood copper and colbalt contents in goats reared around lead-zinc smelter. Small Rum. Res., 63, 309-313.

[10] FAO/WHO Expert Committee on Food Additives (June 1999). "Summary and conclusions," in Proceedings of the 53rd Meeting Joint FAO/WHO Expert Committee on Food Additives, Rome, Italy.

[11] Moses, M. F. and Prabakaran, J. J. (2011). Evaluation of Occupational Exposure to Toxic Metals using Fingernailsas Biological Indicators. Res. J. Environ. Toxicol., 5 (1), 65-70.

[12] Amusan A.A, Ige D.V, Olawale R (2005). Characteristics of soils and crop uptake of metals in municipal waste dumpsite. Journal of Human ecology. $3^{\text {rd }}$ edition volume 17: pages $167-171$.

[13] Udosen E D, Benson N U, Essien J P and Ebong G A, 2006 Int J Soil Sci, , 1, 27-32.

[14] Udosen E D, Journal of Applied Chemistry of Agricultural Research, 1994, 35- 42.

[15] Ogundiran M.B, Ogundele D.T, Afolayan P.G, Osibanjo O. (2012). "Heavy metal levels in Forage Grasses, Leachates, and Lactating Cows Reared around Lead Slag Dumpsites in Nigeria". International journal of environmental research. $3^{\text {rd }}$ editionVolume6 Pages 695-762.

[16] Minervino, A. H. H., Junior, R. A. B., Ferreira, R. N. F., Rodrigues, F. A. M. L., Headley, S. A., Mori, C. S. and Ortolani, E. L. (2009). Clinical observations of cattle and buffalos with experimentally induced chronic copper poisoning. Res. Vet. Sci., 87, 473478 